\title{
Menangani Masalah Konflik Agama
}

\author{
Yusuf Umma
}

\section{Pendahuluan}

Tidak terasa sudah lima tahun usia era reformasi di tanah air. Pada masa ini, rakyat Indonesia berjuang keras dalam melaksanakan agendaagenda reformasi. Pemerintah, tokoh masyarakat dan tokoh agama bersama umat masing-masing berperan secara aktif guna memperbaiki dan meningkatkan kwalitas hidup masyarakat Indonesia.

Kendati demikian, harus diakui bahwa hampir sepanjang usia reformasi, berbagai daerah di tanah air ini dicemari, dirusak dan bahkan dihancurkan oleh berbagai konflik dan kerusuhan sosial. Suatu kerusuhan yang sedemikian rupa sehingga sulit dibayangkan bahwa hal itu dilakukan oleh orang-orang yang menyebut diri sebagai orang yang beragama. Mengomentari kerusuhan tersebut, Dr. M. Qasim Mathar dari IAIN Makassar, mengatakan: "Ironisnya, konflik dan kerusuhan itu mewujudkan dirinya dalam bentuk yang sungguhsungguh tidak manusiawi ketika nuansa keagamaan ditiupkan ke dalam konflik dan kerusuhan itu. Yang menjadi korban, tentu umat dari agamaagama yang berkonflik. Padahal, secara normatif, semua agama mengandung ajaran kemanusiaan yang amat luhur dan sangat menghargai nyawa, hidup manusia, serta kedamaian dalam arti yang sesungguhnya." 1

Krisis dan konflik yang berkembang menjadi kerusuhan berdarah yang menimbulkan bencana kemanusiaan di tanah air membonceng pada issue agama dan kesenjangan akibat ketidakadilan. Hal ini diakui oleh Yusuf Kalla, Menteri Koordinator Kesejahteraan Sosial, yang berbicara dalam dialog khusus di Studio SCTV, bahwa Perasaan ketidakadilan

${ }^{1}$ M. Qasim Mathar, "Pluralisme, Dialog dan Konflik dari Perspektif Islam", Seminar sehari dengan tema: Pluralisme, Konflik dan Pemberdayaan Untuk Rekonsiliasi, dalam rangka HUT ke-37 Gereja Toraja Jemaat Elim (Palu, 16 April 2003), hal. 1 
rupanya yang memicu konflik di Tanah Air. Perasaan itu, menurut Yusuf Kalla, berkembang menjadi letupan-letupan pada permulaan era reformasi. Saat itu, kata dia, hukum tak tegas, sehingga konflik mudah terjadi. $^{2}$ Karena itu, peranan gereja harus diaktualisasi secara benar, maksimal dan optimal untuk menciptakan dan menghadirkan keadilan di dalam seluruh aspek kehidupan masyarakat.

Dalam rangka penerbitan Jurnal STTJ, maka pembahasan berikut ini khusus menyoroti apa dan bagaimana cara penanggulangan masalah konflik yang terjadi di tanah air belakangan ini.

\section{Penanggulangan Praktis}

Sejak kemerdekaan Tanah Air kita diproklamirkan pada tanggal 17 Agustus 1945 dan tersusunnya UUD 45 yang berdasarkan Pancasila, salah satu sila di antaranya menyatakan: bahwa setiap warga negara RI bebas beribadah menurut keyakinannya masing-masing. ${ }^{3}$ Namun demikian, dalam beberapa tahun terakhir ini, konflik horizontal bernuansa SARA yang memakan banyak korban, baik nyawa maupun harta benda, terjadi di berbagai daerah di tanah air. Indonesia yang terdiri dari sekitar 13.500 pulau dan berpenduduk sekitar 220 juta jiwa terus diwarnai oleh berbagai kerusuhan yang membawa bencana kemanusiaan. ${ }^{4}$ Sebagai contoh: kerusuhan Ambon dan kerusuhan Poso yang terjadi hampir secara bersamaan.

Terhadap situasi yang sedemikian ini, gereja merupakan cara yang sangat cocok untuk melayani kebutuhan-kebutuhan masyarakat dan memperkembangkan rencana-rencana praktis untuk menolong orang-orang yang berkonflik dan atau orang-orang yang terimbas dampak konflik. Baik dukungan praktis maupun moral sangat diperlukan. Sebagai contoh, penulis menyebutkan tentang apa yang dilakukan "Crisis Center GKST" di Tentena, Poso, Sulawesi Tengah. Demikian juga yang dilakukan oleh berbagai denominasi gereja, yayasanyayasan dan lembaga-lembaga swadaya masyarakat kristen, yang banyak mengambil bagian dan memberi dukungan kepada mereka yang menderita karena konflik Poso, tidak perduli apa agamanya.

2 Yusuf Kalla dalam dialog khusus di Studio SCTV, Jakarta, 01 Mei 2003 Pukul 08.08 WIB..

${ }^{3}$ Rivai Burhanuddin, Persahabatan Umat Allah. (Jakarta: Penerbit Persahabatan, tanpa tahun), hal. ix

${ }^{4}$ Rina, Ed., Batu-Batu Tersembunyi Dalam Pondasi Kita. (Surabaya: Yayasan Kasih Dalam Perbuatan, 2002), hal. 147 
Apa dan berapapun pertolongan yang diberikan pada waktuwaktu yang sulit seperti itu akan dilihat sebagai perbuatan yang sangat luhur dan akan tercatat di hati sanubari yang pasti sangat sulit untuk dilupakan.

\section{Pendidikan}

Pada umumnya para pakar di bidang masalah-masalah sosial berkomentar bahwa kebanyakan konflik terjadi pada level grass root yang termakan provokasi dari orang-orang yang mempunyai kepentingankepentingan tertentu. Orang lain berpendapat bahwa konflik terjadi karena kurangnya pemahaman terhadap apa yang disebut "unity in diverssity" atau kebersatuan di dalam kepelbagaian.

Di sini orang-orang kristen dapat menolong, baik dengan memberikan informasi maupun dengan menyediakan dukungan, yaitu dengan menunjukkan perhatian khusus baik selama masa konflik terjadi maupun sesudahnya.

Gereja harus menggumuli masalah ini dengan memberikan ceramah-ceramah kepada masyarakat melalui kelas-kelas ekonomi, ilmu pengetahuan, wawasan kebangsaan, dan kelas-kelas lainnya ${ }^{5}$ dengan menjelaskan pentingnya hidup rukun dan damai antar sesama warga masyarakat. Juga perlu dibeberkan tentang akibat-akibat, baik langsung maupun tak langsung, dari konflik yang terjadi. Dengan demikian, kesadaran warga masyarakat terhadap bahaya yang akan timbul akibat konflik (apapun bentuknya), dapat ditingkatkan sehingga mereka tidak lagi mudah diprovokasi oleh pihak-pihak yang tidak bertanggung jawab.

Dengan kata lain, dibutuhkan pencerdasan warga dalam beragama dan dalam berdemokrasi. Pencerdasan dilakukan dengan menanamkan makna keadilan yang harus dijadikan sikap dan perilaku untuk dapat hidup bersama dengan sesama dan bahkan dengan lingkungan. Merasa bersalah jika berbuat jahat, merasa malu jika tidak berbuat kebaikan, dan merasa takut karena berbuat salah menjadi dasar untuk berbuat adil atau untuk tidak menganiaya dan merugikan orang lain atau merusak alam yang merupakan sumber pemenuhan kebutuhan manusia.

Selain daripada itu, perlu pula menumbuhkan sikap menerima pluralitas dan toleransi. Dr. Qasim Mathar menegaskan bahwa, "Pluralitas dan toleransi ... bukan sekedar prosedur dan pengakuan

${ }^{5}$ Bandingkan dengan tulisan Victor Silaen, "Menjadi Berkat Bagi Negara dan Bangsa" dalam buku: 30 Tahun Perkantas: Visi $\mathcal{E}$ Kontinuitas. (Jakarta: Kantor Nasional Perkantas, 2001), hal. 162. 
bahwa kita majemuk, beraneka ragam, terdiri dari bermacam-macam suku, agama dan golongan ... Pluralitas harus disikapi, termasuk dalam tindakan, sebagai tali keberadaban yang menghubungkan sekian banyak keanekaragaman di antara kita." 6

Kepada warga (gereja) perlu ditanamkan ajaran firman Tuhan yang sangat luhur itu., yang berlaku turun temurun, dan bahkan sampai pada hari ini. Misalnya:

"Kasihilah musuhmu, berbuatlah baik kepada orang-orang yang membenci kamu; mintalah berkat bagi orang-orang yang mengutuk kamu; berdoalah bagi orang yang mencaci kamu" (Lukas 6:27-28).

"Jikalau dunia membenci kamu, ingatlah bahwa ia tlah lebih dahulu membenci AKU daripada kamu. Sekiranya kamu dari dunia, tentulah dunia mengasihi kamu sebagai miliknya. Tetapi karena kamu bukan dari dunia, melainkan AKU telah memilih kamu dari dunia, sebab itulah dunia membenci kamu" (Yohanes 15:18-19).

"Barangsiapa menampar pipimu yang satu, berikanlah juga kepadanya pipimu yang lain" (Lukas 6:29).

Jika hal-hal ini dipahami dengan baik dan diamalkan dalam kehidupan bermasyarakat, maka pasti kecenderungan untuk berkonflik, paling kurang dapat diperkecil atau diturunkan.

\section{Campur Tangan Pemerintah}

Pada masa kini peran dan tindakan pemerintah (sangat) kurang memadai dalam menangani konflik yang terjadi di berbagai daerah di tanah air. Para penanggung jawab di bidang keamanan dan ketertiban serta para penegak hukum kurang meresponi bencana kemanusiaan yang sudah dan sedang terjadi.

Sampai sekarang, gereja-gereja Protestan dan gereja-gereja Injili masih belum maksimal dalam menghadapi issue ini. Kesannya bahwa hanya kelompok-kelompok tertentu yang berani menyuarakan penderitaan karena berbagai konflik yang terjadi. Tak dapat disangkal bahwa sekarang denominasi-denominasi Injili mulai menghadapi issue ini dengan menyediakan brosur-brosur, paper-paper, majalah-majalah untuk jemaat mereka.

Barangkali sudah saatnya sekarang untuk pemerintah campur tangan secara inten dalam menangani berbagai konflik yang terjadi. Memang kita tidak mengharapkan dari pemerintah semua jawaban untuk masalah ini. Kita mau supaya kepurtusan-keputusan mereka

${ }^{6}$ Qasim Mathar, Pluralisme ..., hal. 8 
(pemerintah itu), para pembuat undang-undang, petugas keamanan dan penegak hukum, mendemonstrasikan kehormatan untuk kehidupan manusia. Semua unsur terkait perlu insaf atau menyadari issue-issue yang real dan yang baik untuk memperkokoh dan memelihara harkat dan martabat manusia

Beberapa hal dapat diajukan kepada pemerintah sebagai bahan pertimbangan yang mungkin dapat menjelaskan peranannya, antara lain:

(1) Sebagai penyelenggara keadilan, pemerintah mempunyai peranan yang sah sehubungan dengan keputusan menyangkut kehidupan dan kematian. Kita beranggapan bahwa setiap orang, tanpa kecuali, di Republik ini mempunyai hak hidup yang sama, sebab itu, pemerintah tidak boleh melalaikan tanggung jawabnya dengan hanya memutuskan bahwa semua orang harus menghargai dan menghormati sesamanya, tetapi tidak mengambil tindakan ketika ada orang yang menginjak-injak hak hidup orang lain.

(2) Pemerintah bertanggung jawab untuk menjaga kehidupan manusia pada semua situasi dan keadaan. Walaupun dalam satu keadaan yang luar biasa, misalnya: waktu perang, terdapat suatu kekecualian, pemerintah harus melaksanakan tanggung jawabnya dengan satu prasangka yang memihak kepada pemeliharaan kehidupan manusia.

(3) Demi memenuhi tanggung jawabnya dalam hal memelihara kehidupan manusia, pemerintah harus menjamin bahwa keadaankeadaan yang mendukung kehidupan manusia berada dalam lingkungan kekuasaannya. Dalam mendukung kehidupan ini, masyarakat juga perlu diinsafkan akan tanggung jawabnya satu terhadap yang lain dalam segala hubungan dengan kehidupan. Pemerintah patut menyediakan dukungan untuk masyarakat yang tidak mempunyai penghasilan yang cukup untuk menjamin hidupnya dan untuk mengurangi kesenjangan yang ada. Pada waktu yang sama pemerintah patut juga mengumpulkan anggota masyarakat yang dipimpinnya untuk menginsafkan mereka akan tanggung jawabnya dalam bermasyarakat.

(4) Setiap kebijaksanaan umum mengenai kehidupan manusia harus ditempatkan dalam konteks kebijaksanaan mengenai hubungan sosial kemasyarakatan. Pemerintah bertanggung jawab untuk memelihara kehidupan setiap orang. Pemerintah patut membantu kelangsungan hidup dan menolong menciptakan satu lingkungan yang positif di mana setiap orang patut menerima tanggung jawab dan kesukaan dalam hubungannya satu dengan yang lain. 
(5) Pemerintah patut bertindak untuk memperbaiki pengertian masyarakat tentang issue ini. Mereka yang tidak menghargai kehidupan sesamanya patut didorong untuk mempertimbangkan kembali kesimpulan mereka. Mereka yang hampir sama sekali tidak memperdulikan situasi-situasi yang dialami sesamanya patut didorong untuk menunjukkan lebih banyak belas kasihan dan memberikan perhatian yang sesuai dengan kebijaksanaan yang positif yang mendukung kehidupan.

\section{Respon Orang-Orang Kristen}

Sebagai orang-orang yang percaya kepada Yesus Kristus, kita harus memberikan respon dengan satu praduga bahwa semua kehidupan manusia bernilai, baik yang beragama ini maupun yang beragama itu. Kita harus berdiri teguh dan mendukung pendirian yang Alkitabiah yang beranggapan bahwa semua kehidupan manusia berharga di mata Tuhan. Kita patut mendukung anggapan bahwa kita tidak berhak menentukan siapa yang layak untuk hidup dan siapa yang tidak di suatu negeri. Orang-orang kristen harus melibatkan diri dalam issue-issue kemanusiaan, maksudnya orang-orang kristen harus berbuat sesuatu. Timbul pertanyaan, apakah yang dapat kita lakukan?

Berikut ini penulis akan mendaftarkan beberapa hal yang orangorang kristen dapat lakukan, antara lain:

(1) Berdoa, minta pimpinan dan campur tangan Tuhan. Alkitab, berkata, "Doa orang yang benar bila dengan yakin didoakan sangat besar kuasanya" (Yakobus 5:16b). "Kamu tidak memperoleh apa-apa karena kamu tidak berdoa" (Yakobus 4:2b).

(2) Menulis artikel-artikel baik tentang pengertian konflik maupun dampak-dampaknya untuk dapat dimuat di surat kabar atau di majalah-majalah.

(3) Mengusulkan kepada pemerintah agar mengambil tindakantindakan konkrit dalam menangani masalah konflik, termasuk yang bernuansa SARA. Penulis sepakat dengan aktivis kemanusiaan, Imam Prasodjo, pada suatu saat ketika ia berada di tempat pengungsian warga Maluku di Bitung, Sulawesi Utara, yang memberikan nilai plus kepada pemerintah dalam menangani pengungsi, tetapi menyayangkan bahwa sejumlah janji pemerintah tidak terealisir.?

${ }^{7}$ Imam Prasodjo dalam Dialog Khusus Liputan6.com Jakarta, 01-05-2003 Pukul 08:08 WIB. 
(4) Mendesak gembala-gembala sidang jemaat dan pemimpinpemimpin kristen untuk memberikan penerangan tentang cara bagaimana meredahkan dendam dan amarah yang menyulut terjadinya konflik.

(5) Mendorong semua warga gereja untuk menghindari terjadinya konflik horisontal dengan sesama warga masyarakat lainnya.

(6) Membentuk panitia-panitia yang berbeban untuk keperluan sosial di dalam gereja dan masyarakat.

(7) Menyediakan buku-buku ${ }^{8}$, kaset-kaset, audio-visual, buletinbuletin yang dapat memberi pengertian baik untuk diri sendiri maupun untuk orang lain tentang akibat konflik.

(8) Menyingkapkan kerusakan rohani, fisik dan psikis yang dialami oleh orang-orang yang mengalami konflik.

(9) Berbicara kepada orang lain. Nabi Yehezkiel memperingatkan bahwa bila kita tidak memberikan peringatan kepada orangorang yang melakukan kesalahan (dosa), Allah akan menghukum mereka dan kita; tetapi bila kita memberikan peringatan kepada mereka dan mereka masih melakukan yang jahat itu, Allah akan menghukum mereka, tetapi kita tidak, karena kita sudah memenuhi tanggung jawab kita (Yehezkiel 33:8-9). Dalam Amsal 24:11-12, firman Tuhan berkata, "Bebaskan mereka yang diangkut untuk dibunuh, selamatkan orang yang terhuyung-huyung menuju tempat pemancungan. Kalau engkau berkata: sungguh kami tidak tahu hal itu. Apakah Dia yang menguji hati tidak tahu yang sebenarnya? A pakah Dia yang menjaga jiwamu tidak mengetahuinya, dan membalas manusia menurut perbuatannya?"

(10) Mendukung organisasi atau lembaga-lembaga yang berdiri teguh pada pendirian yang anti kekerasan dan anti konflik.

Semua hal ini tidak gampang untuk dilakukan, bahkan tidak menyenangkan. Namun kita dapat memohon kepada Allah agar Ia mendorong dan memampukan kita untuk melakukannya sebagai satu respon kita kepada firmanNya dan terhadap situasi-situasi aktual di sekifar kita.

${ }^{8}$ Contoh buku, antara lain: Suku Pedoman Pembinain Kerukunan Hidup Beragama; Laporan-laporan penyelerggaraan dialog (berupa stensilan), juga Garis-Garis Besar Haluan Nega. ( $3 H N$ ) tahun 1978, khususnya: Pembangunan di bidang Agama dur Kepercayaan terhadap Tuhan Yang Míaha Esa, Sosial Budaya. 


\section{Keterbukaan, Toleransi dan Dialog}

Menyadari bahwa pluralitas adalah suatu kenyataan hidup manusia, maka gereja harus memiliki sikap keterbukaan, toleransi dan dialog. Keterbukaan menuntut pengakuan akan kekurangan dan kelemahan yang terdapat pada diri sendiri, disamping kelebihan dan kekuatan yang dimiliki. Dengan kata lain, keterbukaan menuntut pengakuan terhadap kelebihan dan kekuatan pihak lain.

Toleransi, dalam hal bermasyarakat dan bukan dalam soal beriman, ${ }^{9}$ menuntut ketulusan dan kelapangan dada di dalam menerima kehadiran pihak lain di sekitar kita. Harus diakui bahwa kepelbagaian adalah suatu realita yang tidak dapat disangkal.

Dialog sebagai upaya bersama melalui kerja sama sosial untuk membangun kepercayaan dan saling pengertian serta persaudaraan di antara berbagai kelompok komunitas yang berbeda, menuntut tingkat pengetahuan dan kearifan tertentu. Memang dialog menuntut cara-cara dan prosedur-prosedur yang baik di dalam mewujudkannya, tetapi dengan menyadari bahwa kemajemukan adalah suatu kenyataan di dunia ini, maka dialog perlu ditumbuhkan secara terus menerus dan berkesinambungan.

Dr. Zakaria Ngelow, Ketua STT Intim Makassar, ketika berbicara tentang dialog keadilan, ${ }^{10}$ menyebutkan tiga hal penting, yaitu:

(1) Pluralitas sosial yang sering diwarnai konflik membutuhkan dialog sebagai cara terbaik untuk dapat hidup bersama dalam persaudaraan yang damai.

(2) Dialog keadilan merujuk pada kaitan mendasar antara perdamaian dan keadilan sosial, di mana dialog terarah pada kesepahaman mengenai arti dan usaha-usaha bersama melawan ketidakadilan.

(3) Keadilan dan ketidakadilan bergerak bagai jentera kehidupan, sebab itu dialog bukanlah urusan sekali tuntas melainkan perjuangan bersama terus-menerus.

Dalam Alkitab, yang diakui dan diterima oleh umat Kristen sebagai Firman Allah dan yang merupakan otoritas tertinggi, dikatakan demikian:

"Kasih dan kesetiaan akan bertemu, keadilan dan damai sejahtera akan bercium-ciuman. Kesetiaan akan tumbuh dari bumi, dan keadilan akan menjenguk dari langit" (Mazmur 85:11-12)

${ }^{9}$ Penulis berpendapat bahwa iman tidak dapat ditoleransikan karena iman itu bersifat eksklusip.

${ }^{10}$ Zakaria Ngelow, "Pluralitas, Konflik dan Dialog dari Perspektif Kristen" Seminar sehari dengan tema: Pluralisme, Konflik dan Pemberdayaan Untuk Rekonsiliasi, dalam rangka HUT ke-37 Gereja Toraja Jemaat Elim (Palu, 16 April 2003), hal. 1 
“...Kejarlah keadilan, kesetiaan, kasih dan damai bersama-sama dengan mereka yang berseru kepada Tuhan dengan hati yang murni" (2Timotius 2:22)

"Dan oleh Dialah Ia memperdamaikan segala sesuatu dengan diriNya, baik yang ada di bumi, maupun yang ada di Sorga, sesudah Ia mengadakan pendamaian oleh darah salib Kristus" (Kolose 1:20).

"Saudara-saudaraku yang kekasih, marilah kita saling mengasihi, sebab kasih itu berasal dari Allah; dan setiap orang yang mengasihi, lahir dari Allah dan mengenal Allah. Barangsiapa tidak mengasihi, ia tidak mengenal Allah, sebab Allah adalah kasih" (1Yohanes 4:7-8).

"Ujilah segala sesuatu dan peganglah yang baik. Jauhkanlah dirimu dari segala jenis kejahatan." (1Tesalonika 5:21-22).

Inilah dasar bagi setiap orang yang merindukan kehidupan dan suasana saling mengasihi. Senada dengan ini, Rivai Burhanuddin, mengatakan "... pemikiran bersahabat serta saling kasih mengasihi itu, sangat diperlukan pada masa kita sedang mengikuti rencana pemerintah NRI yang sedang membangun dalam segala bidang dewasa ini, demi untuk mengisi kemerdekaan tanah air kita yang telah dianugerahkan oleh Tuhan kepada semua rakyat Indonesia ini."11

\section{Pergumulan Masa Depan}

Mengharapkan suatu masa depan yang lebih baik bagi semua pihak, khususnya bagi umat yang beraneka agama, yang hidup bersama sebagai satu bangsa, merupakan suatu impian yang terlalu indah sehingga tidak mudah untuk mencapainya. Kesamaan visi dan misi perlu digalang dalam usaha membangun "civil sosiety", bahkan komitmen bersama untuk masyarakat yang damai dan bersahabat serta yang anti kekerasan perlu diperkuat.

Penulis merasa lega ketika Liputan6.com memberitakan bahwa pemerintah akan meniadakan penyebab konflik untuk menyelesaikan pertikaian di daerah. ${ }^{12}$ Kita berharap bahwa janji pemerintah ini tidak sekedar janji belaka, tetapi sesuatu yang dapat direalisasikan dalam kehidupan yang nyata.

Alangkah baiknya, kalau semua umat manusia pada masa modern ini, dapat menunjukkan persahabatan yang akrab dalam membangun "kesatuan dalam kebhinnekaan". Yang dapat mengikat seluruh kelompok masyarakat yang majemuk ini adalah keberhasilan di dalam menegakkan keadilan baik dalam beragama maupun dalam berdemokrasi serta keadilan dalam berbagai bidang kehidupan lainnya.

${ }^{11}$ Rivai Burhanuddin, Ibid, hal. $x$

${ }^{12}$ Berita dari "Liputan6.com" Jakarta, 01 Mei 2003 Pukul 08.08 BIB. 